\title{
Investigating the subjective well-being of the informally employed: A case study of day labourers in Windhoek and Pretoria
}

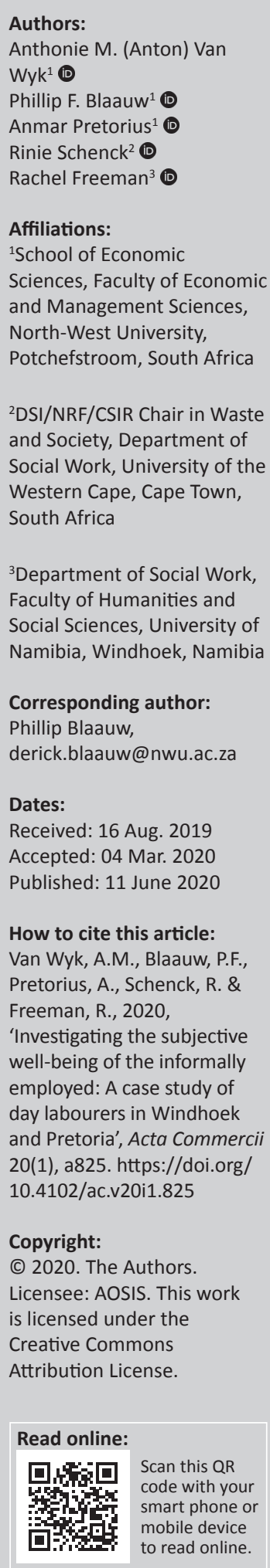

Orientation: Day labouring is becoming more frequent in developing countries. Long spells of unemployment and the uncertainty of informal wage employment impact negatively on the subjective well-being (SWB) of day labourers.

Research purpose: The aim of the article was to investigate the level and possible determinants of the SWB of day labourers in Pretoria and Windhoek.

Motivation for the study: Up to now, only one study has been carried out in South Africa on the SWB of day labourers and none in Namibia. This study aimed to start filling this gap in the literature. The choice of the two cities was based on their status as the capital cities of two countries that are both experiencing increasing numbers of day labourers.

Research design, approach and method: A mixed-method research design and purposeful sampling were used to obtain representative samples. Data were sourced from comparable surveys amongst day labourers in the two cities between 2015 and 2017. Questionnaires with quantitative and qualitative sections were completed during structured interviews with 290 and 80 day labourers in Pretoria and Windhoek respectively. The ordinary least squares model and ordered-probit analysis were employed to analyse the data.

Main findings: In Pretoria, the number of dependents, the living conditions and whether they had a full-time job before were all significant in explaining the SWB of the day labourers. In Windhoek, education levels, total days without food, staying with their families and being a foreigner were also significant.

Practical/managerial implications: The needs of the informally employed must be addressed in the integrated development plans of municipalities and integrated with day labour worker centres.

Contribution/value-add: This is the first study to analyse SWB amongst day labourers in Namibia and lays the foundation for future expanded studies.

Keywords: informal economy; day labourers; subjective well-being; informal employment; temporary employment; well-being.

\section{Introduction}

Persistent high levels of unemployment have been a constant theme of the South African macroeconomic environment over many years. The latest statistics in this regard, however, seem more sobering than ever.

According to the official definition of unemployment, the latest figure puts unemployment in South Africa, which is the 103rd happiest country in the world, at $29.1 \%$ in the fourth quarter of 2019. Youth unemployment is more than 50\% (Helliwell, Huang \& Wang 2019; Statistics South Africa 2020). These are the highest levels of unemployment since 2008 and the onset of the world financial crisis. The expanded definition of unemployment, which includes those who are no longer looking for work, is $38.5 \%$. This represents more than 10 million people (Statistics South Africa 2020). To put this into further perspective: South Africa, with a population of around $58 \mathrm{~m}$ people, has the same absolute number of unemployed people than the USA, with a population of around $320 \mathrm{~m}$ people. Namibia, which is the 113th happiest country in the world (Helliwell et al. 2019), faces similar problems of unemployment. The Namibian unemployment rate (measured using the same definition) was even higher at 33.4\% in 2018 (Tradingeconomics 2019).

Many of the unemployed in both countries venture into the informal economy in an effort to earn some form of income. According to Statistics South Africa (2020), the informal employment 
rate in South Africa is approximately $17.26 \%$. According to the latest publically available Namibian Labour Force Survey (2016), the informal employment rate of the country is 66.5\% (Namibia Statistics Agency 2016). These statistics show that proportionally fewer people depend on being informally employed in South Africa to care for themselves and their families, and more depend on informal work in Namibia.

Many unemployed people are therefore active in the informal economy in South Africa and Namibia, where they engage in a variety of survivalist activities, such as day labouring (Blaauw, Botha \& Schenck 2018). Individual unemployment forces scores of men and women in South Africa to offer their services on the street corners and at intersections to make some sort of living and care for their families. Blaauw et al. (2018) found that this activity is characterised by high search cost and uncertainty of the level of income the day labourers will receive for a day's work. Past research also provided evidence of the negative social impacts that extended spells of individual unemployment can have on people's subjective well-being (SWB) (Diener \& Chan 2011). The question that requires attention from researchers is: What is the impact of being unemployed or being infrequently employed as a day labourer at best, on the SWB of day labourers in South Africa and Namibia? This formed the central aim and objective of this study.

Subjective well-being is a topic that has been given increasing levels of attention as a field of study in economics (Blanchflower \& Oswald 2004; Easterlin 2001; MacKerron 2012). However, thus far, little focus has been given to the informal sector (Blaauw et al. 2013, 2018). In fact, the authors found only one study carried out on the SWB of day labourers in South Africa (Blaauw et al. 2018) and none in Namibia. This article therefore aimed to contribute to the limited scientific literature that specifically focusses on SWB in the informal sector.

The objective of this study was to investigate the determinants of the SWB of the day labourers in Pretoria and Windhoek. Because of the limited research on this topic, this study aimed to make a contribution to fill the gap that exists within the SWB literature, focusing on the informal economy.

To complement the main objective of the study, the following secondary objectives were identified: to determine the level of the SWB (self-reported happiness) of the day labourers in Pretoria and Windhoek; to determine the possible factors that can influence the SWB of day labourers in the capitals of the two countries; to identify possible reasons for the differences in the SWB of the day labourers; and to compare the results of the study with other SWB studies in the informal economy.

\section{Literature review: Concept and determinants of subjective well-being}

Richard Easterlin can be seen as a pioneer in the research of SWB or happiness studies. He invented what is today known as the happiness income paradox (HIP), more commonly known as the Easterlin paradox. The paradox can be explained as follows: At any point in time, not only amongst nations but also within nations, the happiness of people varies directly with income, but over time, as the income of a country increases, it is not usually the case with the happiness of the people (Easterlin et al. 2010:1).

Over time, researchers came to the belief that a person has to decide for himself or herself whether he or she is happy with his or her life. Diener (2009) states that SWB can be defined as a person's cognitive and effective evaluations of his or her life. Diener further states that perceptions of satisfaction and fulfilment are some of the cognitive judgements that are included by people when evaluating their SWB.

Other researchers have similar definitions for SWB. An example of this is the definition of Diener, Oishi and Lucas (2003), who state that SWB is the scientific analysis of how people evaluate their lives. This definition is close to the definitions of both Diener (1984) and Proctor (2014). Proctor (2014) specifically indicates that SWB can be measured by using self-reporting. This means that the respondents will give their own view of how happy they are with their current life situation.

According to Andrews and Whitey (1976), SWB has three components. These components are life satisfaction, positive affect and negative affect.

Rojas (2013) points out that studies focussing on informality from an SWB approach are fairly limited. In his study on SWB and informal employment in Mexico, he found that the informally employed often display lower job satisfaction and lower satisfaction with their working schedule than their formally employed counterparts (Rojas 2013). More importantly, these differences are significantly explained by observable variances in the characteristics of people who are working in the formal and informal sector and not by informality itself. These characteristics include lower educational attainment, poorer health and lower income than people in formal employment (Rojas 2013) - characteristics often attributed to day labourers.

Considering previous studies carried out on the SWB of day labourers in particular, there is one study conducted in South Africa, but none for Windhoek or the greater Namibia. Blaauw et al. (2018) conducted a study on income and geographical location regarding the SWB of day labourers in South Africa. The study concludes that more and more day labourers flock to the cities in the hope that they will receive better work for a higher income (Blaauw et al. 2018). Unbeknown to them, by doing this, they in fact increase the overall competition for jobs because they are not the only ones migrating to bigger cities for better opportunities.

More studies are available for the general study of SWB in South Africa. According to Botha and Booysen (2011), the overall life satisfaction of South African adults is considerably 
higher for married people compared wih widowed individuals. Unlike the developed world, respondents' height, health and whether they reside in urban or rural areas do not explain SWB in South Africa.

Surprisingly, religion and provincial location strongly determine SWB in South Africa (Blaauw \& Pretorius 2012).

Mahadea and Ramroop (2015) state that statistically significant relationships exist between SWB and variables such as gender, education, children, marital status, employment and income. The study found that people are happier and have higher levels of SWB when they are married and have children. In turn, having too many dependants can have negative effects on the SWB of those caring for them.

Møller and Devey (2003) indicated that the largest part of the older generation in South Africa does not receive much income and live in households with many of their children and grandchildren. Households that are older and poor but have better access to services will report higher levels of SWB and overall satisfaction with the circumstances they are living in (Møller \& Devey 2003). One of the factors that lift workers and older households out of poverty is the socalled state old-age pension grant. This is a grant given to people who are retired and receive no or a limited income (Møller \& Devey 2003). Møller and Schlemmer (1989) also indicate that education is important for quality of life and SWB. The well-being of individuals in a divided society should rise above racial and class divisions (Møller \& Schlemmer 1989).

In summary, when looking at the possible determinants of SWB, the literature concludes that there are certain standard variables that are linked to life satisfaction (Møller 2007). These are almost always included in estimated functions. Furthermore, these determinants hold across countries and across time (Greyling 2018). South African studies also use these particular variables. Blaauw and Pretorius (2012) explored the determinants of SWB in South Africa, by using the first available wave of the National Income Dynamics Study. Variables such as age, race (being a white person within the context of South Africa (Posel \& Casale 2011), level of income, total years of education, gender, marital status and the number of children or dependants can play a role in explaining SWB in South Africa (Blaauw \& Pretorius 2012).

These variables consistently feature throughout the South African and international literature (Blaauw \& Pretorius 2012). Apart from income levels, it is found that religious activities, social trust, physical exercise and marital status all play a role in the SWB of individuals (Botha \& Booysen 2011).

Blaauw and Pretorius (2012) also stated that individuals who saw religion as an important aspect of their lives proved to have higher levels of SWB than people who are not religious. In a recent South African study, Greyling (2018) found that Internet access is positively related to SWB (Greyling 2018).
This relationship applied across all race groups and all age groups, from 18 years to over 65 (Greyling 2018:1). The most recent South African study found by the authors was the work of Van Aardt, De Clercq and Meiring (2019). They utilised a newly developed conceptual framework to challenge the linear influence of a variety of determinants of happiness. Their results suggest that a stochastic happiness determination path exists from underlying to non-proximate, to proximate to happiness outcomes. This casts doubt over the linear path as suggested in the traditional approach. Policymakers in South Africa therefore must rethink their current strategies to improve the quality of life of its citizens (Van Aardt et al. 2019). The variables forthcoming from the literature informed the methodology and empirical approach of this study.

\section{Research methods and design}

The design for this study was informed by previous studies on informal economy activities such as day labouring or waste picking (Valenzuela et al. 2006; Viljoen, Schenck \& Blaauw 2012). The research design used a mixed-method approach, with a survey-based instrument being used with mostly quantitative items, except some open-ended qualitative elements.

The research setting for the study was in Pretoria, South Africa, and in Windhoek, Namibia. The choice of research setting was guided by the fact that, as the capitals of the two countries, they provided the most feasible opportunity to conduct a comparative case-study analysis of the levels and possible determinants of the SWB of day labourers in the two cities. It was necessary to use a creative approach to determine the research population, because of the unique practice of day labouring (Blaauw, Louw \& Schenck 2006; Louw 2007:59). The research process had to fit into the times that the day labourers were available for interviews during the day (Louw 2007:60).

The research population was defined as day labourers who are waiting to be employed for the day at informal hiring sites such as street corners, next to traffic lights, at informal hiring sites or in front of job-related businesses in Pretoria and Windhoek. Those who were just standing at the hiring sites and were already employed and only waiting for transport were excluded from the respondents for this study. The definition for the research population was similar to definitions used in the studies by Valenzuela et al. (2006), Blaauw et al. (2006), Louw (2007) and Blaauw (2010).

The sampling method can be defined as the choosing of a certain part or segment of the research population to be included in the study (Rubin \& Babbie 1997:233). The process of sampling used in the study is guided by the same principles that guided the sampling technique used by Blaauw et al. (2006), Louw (2007) and Blaauw (2010). The sampling informed the number of day labourers who were interviewed. In Windhoek, purposeful sampling was used after all the day labour hiring sites in the city were identified. 
Each hiring site was visited, and all day labourers encountered and who were willing to participate in the research (80 respondents) were interviewed. The sampling procedure in terms of the textbook definition in this case was therefore non-random, but we purposefully interviewed every day labourer present and willing to participate on the days of the fieldwork. Very few day labourers chose not to participate and therefore we are confident that the research population was covered as extensively as possible, because each day labourer had the option to participate in the study should he or she wish to do so.

In Pretoria, 290 day labourers were interviewed. This was the result of visiting all the hiring sites known to the authors as well as the new sites encountered. A minimum of $10 \%$ of the day labourers present at each of these sites were interviewed by the fieldworkers following the same protocols as that of earlier studies in the same areas (Blaauw 2010; Blaauw et al. 2006; Louw 2007). The authors acknowledge that we cannot necessarily claim statistical representativeness of the sample; however, the sampling methods used were consistent and covered the research population in all geographical areas of the city.

Questionnaires were in the form of structured interviews based on studies carried out by Blaauw et al. (2006) and Blaauw (2010). Several questions (income-related) from the Blaauw et al. (2006) and Blaauw (2010) studies were adjusted to provide more meaningful results. Sections were included for employment history, income earned, working conditions, housing and conditions of the hiring sites.

The fieldworkers used in the study were recruited from students, who completed their studies, in Pretoria and in Windhoek who did not yet have permanent employment at the time. Training for the fieldwork was carried out according to the outlines by Rubin and Babbie (1997:356-358). Demonstration and role-play were carried out before the actual fieldwork. Fieldworkers were trained to clearly identify themselves before an interview commenced. The fieldwork to collect the data for Pretoria was carried out in 2015. Hiring sites previously identified were revisited and new sites were also included. The fieldwork for Windhoek was carried out in 2017.

The knowledge of the co-researcher of Windhoek helped to identify hiring sites where day labourers could be interviewed. After completion of the interviews, all the completed questionnaires were scrutinised to make sure that every questionnaire was readable and that all the answers were filled in. All questionnaires that were not readable or incomplete were discarded to make sure that all results were accurate and a correct representation of the population used. The data were captured in Excel and the subsequent analysis carried out in Eviews.

The study adhered to strict ethical elements and principles. It received clearance from both the ethics committees of the
North-West University and the University of the Western Cape. The respondents also had the right to choose not to be included in the interviews and the study, and if they took part, their identities were kept completely anonymous. This was already respected in the design of the questionnaire, where no information was asked that could identify the respondents.

\section{Ethical consideration}

The Senate Research Committee of the University of the Western Cape approved the methodology and ethics of the following research project by Prof. C. Schenck (Social Work).

Research Project: The socio-economic aspects of day labouring in South Africa. Registration no: 14/3/10. Any amendments, extension or other modifications to the protocol must be submitted to the Ethics Committee for approval. The committee must be informed of any serious adverse event and/or termination of the study.

\section{Results}

This section commences with the basic demographics of the day labourers in the two cities in terms of gender, age education, home language and country of origin. This is followed by the model specification and the empirical results of the study.

\section{Gender and age distribution}

Day labourers in Windhoek were almost exclusively male $(98.75 \%)$, whereas Pretoria had a female component of $7.24 \%$.

The age distribution of the day labourers in both cities is indicated in Tables 1 and 2.

As for the education of the day labourers, 34.14\% of respondents in Pretoria completed matric or went on to receive some sort of higher education or training. In Windhoek, only $3.75 \%$ of the respondents completed matric, with only one respondent furthering his studies.

In Windhoek, 65 of the 80 respondents speak Oshivambo, eight of them are Afrikaans speaking, two are English and five are Damara speaking. The results for the Pretoria sample display a wider distribution of languages spoken by the respondents. Of the respondents in Pretoria, 8 speak English, 30 speak Sesotho, 39 speak Sepedi, 20 speak isiZulu, 18 speak isiNdebele, 20 speak Xitsonga, 3 speak Afrikaans, 11 speak Setswana, 6 speak isiXhosa, 10 speak Tshivenda, 2 speak siSwati and 112 speak other languages, most of them from Zimbabwe.

The country of origin for 128 (44\%) of the Pretoria respondents is South Africa. One hundred and forty-two (49\%) are from Zimbabwe, two (0.7\%) are from Mozambique, 10 (3.5\%) are from Lesotho, six (2.1\%) of the respondents are from other 
TABLE 1: Age distribution of the day labourers in Pretoria, 2015.

\begin{tabular}{lccc}
\hline Category & Age (years) & Number of day labourers & Percentage \\
\hline 1 & Under 20 & 0 & 0 \\
2 & $20-25$ & 63 & 21.72 \\
3 & $26-30$ & 89 & 30.69 \\
4 & $31-35$ & 56 & 19.31 \\
5 & $36-40$ & 36 & 12.41 \\
6 & $41-45$ & 16 & 5.52 \\
7 & $46-50$ & 12 & 4.14 \\
8 & $51-55$ & 4 & 1.38 \\
9 & $56-60$ & 7 & 2.41 \\
10 & $>60$ & 6 & 2.07 \\
11 & Refused to answer & 0 & 0 \\
12 & Did not know & 1 & 0.35 \\
Average age & 32.68 years & - & - \\
Median & 30 years & - & - \\
\hline
\end{tabular}

TABLE 2: Age distribution of the day labourers in Windhoek, 2017.

\begin{tabular}{lccc}
\hline Category & Age (years) & Number of day labourers & Percentage \\
\hline 1 & Under 20 & 0 & 0 \\
2 & $20-25$ & 10 & 12.5 \\
3 & $26-30$ & 20 & 25 \\
4 & $31-35$ & 10 & 12.5 \\
5 & $36-40$ & 11 & 13.75 \\
6 & $41-45$ & 10 & 12.5 \\
7 & $46-50$ & 7 & 8.75 \\
8 & $51-55$ & 4 & 5 \\
9 & $56-60$ & 3 & 3.75 \\
10 & $>60$ & 1 & 1.25 \\
11 & Refused to answer & 0 & 0 \\
12 & Did not know & 4 & 5 \\
Average age & 36.44 years & - & - \\
Median & 34 years & - & - \\
\hline
\end{tabular}

countries and two did not state from which country they originate. Seventy-six (95\%) of the respondents from the Windhoek data originate from Namibia, one (1.25\%) respondent is from South Africa, two (2.5\%) are from Angola and one $(1.25 \%)$ originates from Zimbabwe. This illustrates that the day labourers in Windhoek can be regarded as a much more homogenous group than their Pretoria counterparts, where more than half are immigrants from other countries in sub-Saharan Africa. This aspect will also form part of the empirical analysis below.

\section{Model specification, estimation and discussion of results}

Two separate types of estimations were run for Pretoria and Windhoek, respectively. One was an ordinary least squares (OLS) method, and the other was an ordered-probit analysis.

Table 3 provides a description of the variables used for the Pretoria and Windhoek analysis. The dependant variable of both estimations was the self-reported SWB of the day labourers.

This was a question asked to the respondents, to which they had to give the value that best suited their current state of SWB. The question that was asked is as follows: 'On a scale of 1-10 (10 being very happy and 1 very unhappy), how happy are you with life at the moment?' The variable therefore could take the value of 1 to 10 .

Originally, six models were estimated for Pretoria and five models were estimated for Windhoek. Only the models with the best results were included in this article. Income variables are not included in the results, because they were not statistically significant and they were discarded to obtain better results. Different models were then estimated to see what the effect of the different variables on the SWB of the day labourers will be. Age and age-squared were included in the estimations to allow for a quadratic effect of age on the dependant variable. When adding the square root of age, it allows for a parabolic relationship, rather than assuming that the effect is linear for all ages.

\section{Variables used in analysis for Pretoria and Windhoek}

\section{Estimation results}

Two methods of estimations were employed in the study: OLS and ordered-probit. The use of the ordered-probit analysis serves as an appropriate framework in a statistical analysis when the responses from the surveys conducted are ordinal as distinct from numerical (Daykin \& Mofatt 2002; Greene 1993). The ordered-probit model is typically used when questions are asked and answered based on a Likert scale, and is used when studies employ surveys based on opinions to compile data for use, like this study did (Greene 1993). According to Ferrer-i-Carbonell and Frijters (2004), psychologists and sociologists generally use OLS regressions in empirical studies on SWB, although economists tend to employ ordered response models. This study therefore uses both estimation techniques and in most cases the sign and statistical significance of the estimated coefficients correspond.

Tables 4 and 5 and Tables 6 and 7 present the results of the OLS and ordered-probit estimations for Pretoria and Windhoek respectively. All models estimated were corrected for the possibility of heteroscedasticity, using the White's adjustment for heteroscedasticity in the OLS estimations and the Huber or White's adjustment in the ordered-probit estimations.

\section{Pretoria}

The estimations (see Tables 4 and 5) show that the coefficient of the age variable is negative. The reason for the negative coefficient could be explained that as the day labourers get older, their level of SWB decreases, so their productivity also decreases. Furthermore, because day labouring is such a physical job, the day labourers who are older would not be able to do the same number of jobs as their younger counterparts. The negative coefficient may also reflect the fact that at an older age, the day labourer may come to realise that he or she may never be able to secure full-time employment in the formal economy. At a younger age, this may still be a possibility, however, leading to higher levels of SWB. 
TABLE 3: Description of the variables used for the Pretoria and Windhoek analysis

\begin{tabular}{|c|c|c|}
\hline Variable & Description & Predicted value ( \pm ) \\
\hline Subjective well-being (happiness) & $\begin{array}{l}\text { The recorded level of well-being of the day labourers in } \\
\text { the study. The question asked is as follows: 'On a scale of } \\
1-10 \text { ( } 10 \text { being very happy and } 1 \text { very unhappy), how } \\
\text { happy are you with life at the moment?' }\end{array}$ & Dependent variable of the study \\
\hline Age and age ${ }^{2}$ & Age of the day labourers & $\begin{array}{l}\text { Negative for the older day labourers, because productivity } \\
\text { decreases with age }\end{array}$ \\
\hline $\begin{array}{l}\text { Grade (Dummies) } \\
\text { (Dum Some Primary) } \\
\text { (Dum Primary) } \\
\text { (Dum Some Secondary) } \\
\text { (Dum Secondary) } \\
\text { (Dum Post) }\end{array}$ & $\begin{array}{l}\text { Level of education that the day labourers have attained } \\
\text { divided into six categories. The base category for this } \\
\text { dummy variable is no schooling }\end{array}$ & $\begin{array}{l}\text { Positive or negative. It is predicted that the higher the level of } \\
\text { education of the day labourers, the higher their level of subjective } \\
\text { well-being. Another prediction can be that the more educated } \\
\text { labourers would be less happy because they have higher levels of } \\
\text { education, and would expect to be employed and better off with } \\
\text { higher levels of subjective well-being }\end{array}$ \\
\hline Experience & $\begin{array}{l}\text { Years that the respondents have been participating in day } \\
\text { labouring }\end{array}$ & $\begin{array}{l}\text { Positive or negative. The more years' experience a day labourer } \\
\text { has, the better their level of subjective well-being. The reason for } \\
\text { this is because if a labourer has more experience in a certain } \\
\text { skillset, he or she will be more likely to be given a job above } \\
\text { another labourer with less experience, because he or she would be } \\
\text { able to do a better and more thorough job. Alternatively, it can be } \\
\text { negative, as more years without a full-time job can impact } \\
\text { subjective well-being negatively. }\end{array}$ \\
\hline Total dependants & $\begin{array}{l}\text { Number of people dependent on the income received } \\
\text { by the day labourers }\end{array}$ & $\begin{array}{l}\text { Negative. It is expected that given the low income, the level of } \\
\text { subjective well-being will decrease as the number of dependents } \\
\text { increases. }\end{array}$ \\
\hline Living conditions (dummy) (Dum living conditions) & $\begin{array}{l}\text { Type of living arrangement indicated by a value of } 1 \text { if } \\
\text { the labourer lives in a shack and } 0 \text { otherwise. }\end{array}$ & Negative if living in shacks compared with formal housing \\
\hline Total days without food & $\begin{array}{l}\text { Total number of days that the respondents did not have } \\
\text { anything to eat in the preceding month. }\end{array}$ & $\begin{array}{l}\text { Negative. The more days without food the lower their level of } \\
\text { subjective well-being will be. }\end{array}$ \\
\hline Full-time job before (Dummy) (Dum Full before) & $\begin{array}{l}\text { Whether they had a full-time job before started working } \\
\text { as day labourers. The value of the variable is } 1 \text { if they had } \\
\text { a job before starting work as a day labourer and } 0 \text { if they } \\
\text { did not have a full-time job. }\end{array}$ & $\begin{array}{l}\text { Negative. If they had a full-time job before they started day } \\
\text { labouring, they would have lower subjective well-being levels, } \\
\text { because they no longer have a steady monthly income. Working as } \\
\text { day labourers, the respondents do not know whether they will get } \\
\text { a job to care for themselves and their families. }\end{array}$ \\
\hline Stay with family (dummy) (Dum Stay Fam) & $\begin{array}{l}\text { Indication of whether the respondents live with their } \\
\text { families or not. The value is } 1 \text { if they stay with family and } \\
0 \text { if they do not stay with family. }\end{array}$ & $\begin{array}{l}\text { It is expected to be positive because if the labourers live with } \\
\text { their families then they might feel that they have something } \\
\text { to live for and people who care about them, which makes } \\
\text { them happy. }\end{array}$ \\
\hline
\end{tabular}

TABLE 4: Pretoria day labourers' subjective well-being regression 1 results.

\begin{tabular}{lcl}
\hline Variables & \multicolumn{2}{c}{ Model 1 } \\
\cline { 2 - 3 } & Coefficient & $p$ \\
\hline Constant & 7.005192 & $0.0012^{* * *}$ \\
Age & -0.075599 & 0.5287 \\
Age-squared & 0.000653 & 0.6610 \\
Dum Prim & -0.153791 & 0.7953 \\
Experience months & -0.001331 & 0.6703 \\
Tot dependants & -0.144304 & $0.0366^{* *}$ \\
Dum living conditions & -0.596181 & $0.0894^{*}$ \\
Tot days without food & -0.032335 & 0.2775 \\
Dum Afrikaans & 0.537868 & 0.2988 \\
Dum full before & 1.134581 & $0.0019 * * *$ \\
$R$-squared & 0.084058 & - \\
$F$-statistic & 2.620615 & $0.006497^{* * *}$ \\
\hline
\end{tabular}

$*$, Significant at $10 \%$.

**, Significant at $5 \%$

***, Significant at $1 \%$.

The coefficient of the education variable of the data also shows to be negative, and this was as expected. It was predicted that the lower the day labourer's level of education is, the lower their level of SWB will be. This shows that if the day labourers had higher levels of education, than just primary and secondary schooling, then they could possibly have higher levels of SWB. Furthermore, higher levels of education may help the day labourers to be more competitive in the workforce when searching for jobs or applying for a full-time job.
TABLE 5: Pretoria ordered-probit analysis 1.

\begin{tabular}{lcc}
\hline Variables & \multicolumn{2}{c}{ Model 1 } \\
\cline { 2 - 3 } & Coefficient & $p$ \\
\hline Age & -0.032898 & 0.4334 \\
Age-squared & 0.000284 & 0.5859 \\
Dum Some Sec & -0.025137 & 0.8411 \\
Tot dependants & -0.061661 & $0.0268^{* *}$ \\
Dum living conditions & -0.215671 & $0.0961^{*}$ \\
Tot days without food & -0.009062 & 0.4221 \\
Dum Afrikaans & 0.167341 & 0.3747 \\
Dum full before & 0.456517 & $0.0007^{* * *}$ \\
$R$-squared & 0.020196 & - \\
LR-statistic & 23.22081 & $0.003092^{* * * *}$ \\
\hline
\end{tabular}

*, Significant at $10 \%$

**, Significant at $5 \%$.

$* * *$, Significant at $1 \%$

Having to care for a high number of dependants on a small income typically received by day labourers can be stressful. It was expected that the coefficient of the total dependants variable would be negative, and this was the case. The variable is also significant at a $5 \%$ level of significance $(<0.05)$. The reason for the negative coefficient could possibly be attributed to the fact that the day labourers do not receive much money in a month and then have to care for their large families at home. Living conditions are also a very important aspect for one's SWB. In this study, it was expected that the coefficient of the living conditions dummy variable would be 
negative. This was proved to be true in the results of the estimation, and the negative coefficient could be attributed to the fact that the SWB of the day labourers who live in shacks will be negatively affected as opposed to those day labourers who live in formal housing with proper running water, sanitation and electricity. The variable for the living conditions was also significant against a $10 \%$ level of significance $(<0.10)$.

Having a full-time job with a steady monthly income is good for the SWB of a person. It was predicted that if the day labourers had a full-time job before they started working as day labourers, they would have lower levels of SWB and the coefficient of the full-time job before variable would be negative. This was not the case. The coefficient of the variables was proved to be positive and statistically significant. The reason for this positive coefficient could be that the day labourers who were employed previously may have certain levels of skill and experience that increase their chances of securing some of the limited part-time jobs available. This needs to be investigated further with more in-depth qualitative research amongst day labourers in Pretoria.

As predicted, the coefficient for the total days the labourers had to go with little or no food was negative. The longer the day labourers had to go with little or no food to eat, the lower their level of SWB would be. This could be that they would also not be very productive and not be able to do their jobs as well as they would have done if they had something to eat every day. The average number of days per month that the day labourers in Pretoria had to go without food is four days and the median is two.

It was predicted that the variable for the Afrikaans dummy would be positive. The variable was not statistically significant, but the coefficient is as expected. The positive coefficient shows that the day labourers in Pretoria who can speak Afrikaans may find more jobs because Pretoria has a large concentration of Afrikaans-speaking people. If the labourers can help themselves in speaking Afrikaans, the chances of them receiving a job for the day will be higher. It was expected that the variable for the amount of experience a day labourer has would have been positive, but it was proved to be negative in this study. Long spells of being a day labourer may produce negative emotions as the day labourers feel that their chances of obtaining permanent jobs are becoming less every day, explaining the negative sign of the coefficient. The following section discusses the results for the same analysis for Windhoek and comparing that with the Pretoria results.

\section{Windhoek}

In Windhoek (see Tables 6 and 7), the data show that being a day labourer with some secondary schooling could be of positive value for that person. Although the coefficient of the education variable is not significant, the positive sign shows
TABLE 6: Windhoek day labourers' subjective well-being regression 3 results.

\begin{tabular}{lrl}
\hline Variables & \multicolumn{2}{c}{ Model 3 } \\
\cline { 2 - 3 } & Coefficient & $p$ \\
\hline Constant & 9.958110 & $0.0005^{* * *}$ \\
Age & -0.349651 & $0.0179 * *$ \\
Age-squared & 0.003992 & $0.0288^{* *}$ \\
Dum some sec & 0.907263 & 0.1435 \\
Experience & 0.007075 & $0.0132^{* *}$ \\
Tot dependants & 0.164406 & $0.0628^{*}$ \\
Dum living conditions & -0.717789 & 0.1857 \\
Tot days without food & -0.089861 & $0.0966^{*}$ \\
Dum Foreigners & 2.382010 & $0.0298^{* *}$ \\
Dum Stay fam & 1.103389 & $0.0591^{* *}$ \\
Dum Skilled & -0.092355 & 0.8885 \\
$R$-squared & 0.322399 & - \\
F-statistic & 3.045092 & $0.003247 * * *$ \\
\hline
\end{tabular}

*, Significant at $10 \%$.

**, Significant at $5 \%$.

$* * *$, Significant at $1 \%$

TABLE 7: Windhoek day labourers' subjective well-being ordered-probit analysis 2 results.

\begin{tabular}{lcc}
\hline Variables & \multicolumn{2}{c}{ Model 2 } \\
\cline { 2 - 3 } & Coefficient & $p$ \\
\hline Age & -0.195605 & $0.0077^{* * *}$ \\
Age-squared & 0.002291 & $0.0122^{* *}$ \\
Dum some sec & 0.428750 & 0.1618 \\
Experience & 0.003319 & $0.0088^{* * *}$ \\
Tot dependants & 0.086503 & $0.0513^{* *}$ \\
Dum living conditions & -0.443629 & $0.0870^{*}$ \\
Tot days without food & -0.057065 & $0.0880^{*}$ \\
Dum Foreigners & 1.138349 & $0.0294^{* *}$ \\
Dum Stay fam & 0.555326 & $0.0523 * *$ \\
Dum skilled & -0.037916 & 0.9027 \\
$R$-squared & 0.097689 & - \\
LR-statistic & 30.38069 & $0.000742^{* * *}$ \\
\hline
\end{tabular}

*, Significant at $10 \%$.

$* *$, Significant at $5 \%$.

$* * *$, Significant at $1 \%$

that labourers with some secondary schooling will have higher levels of SWB than day labourers who have lower levels of education. When looking at the experience of the day labourers, the data show that the coefficient of the variable is positive. This positive sign could perhaps be explained by the fact that day labourers with more experience will have higher levels of SWB than labourers with less experience, because they can also charge a higher fee for their services. Another, in our view more plausible, explanation could be the manifestation of adaptive expectations. These labourers could have accepted that they do not have a job in the formal sector and probably will not receive a formal job in the near future. The experience variable is also significant at a $1 \%$ level of significance $(<0.01)$.

The coefficient of the total dependants variable was not as expected. It was predicted that the more dependants the day labourers have to care for, the lower their levels of SWB will be, but the coefficient ended up being positive. This variable is also significant at a $5 \%$ level of significance $(>0.05)$. It could be that the day labourers feel good providing for their families and other persons living with them and that family 
size is an important part of their emotional support structure. Again, further qualitative research is needed to probe this interesting finding further. The case of the living conditions of the day labourers in Windhoek was as expected. It was predicted that the coefficient of the living conditions variable would be negative, and the data proved this to be true. These findings echoed that of the Pretoria results. Day labourers who live in shacks will have lower levels of SWB than the labourers who live in more formal types of housing. This variable also proved to be significant at a $10 \%$ level of significance $(<0.10)$.

Only four of the respondents in Windhoek were from another country. It was predicted that the coefficient of the foreigners-variable would be negative, but it was positive. The reason for this could be because there are not that many foreigners amongst the day labourers, so the day labourers in Windhoek would have higher levels of SWB because there are no foreign immigrants from other countries taking their jobs. The variable is significant at a $5 \%$ level of significance. It was predicted that if the day labourers stay with their families, they would have higher levels of SWB, and this was proved to be true in the estimation results. The reason for this could be that if the day labourers stay with their families, the possibility of there being more than one breadwinner for the family could be higher. The burden of being the only person making money to care for the family would be lower, and the level of SWB of the day labourers would be higher. The variable was significant at a $5 \%$ level of significance.

\section{Conclusion, policy implications and future research areas}

The study investigated the SWB of day labourers in Pretoria, South Africa, and in Windhoek, Namibia, with the aim to identify the potential determinants of the SWB of the informally employed day labourers.

Analysis of the Pretoria data revealed that the total number of dependants of the day labourers, the conditions in which the day labourers are living and whether they had a full-time job before starting to work as day labourers were all significant in explaining the SWB of the day labourers in Pretoria. The analysis of the Windhoek data revealed that experience, living conditions, education levels, total number of dependants for which the day labourers have to care, total days without food, whether the labourers stay with their families and whether they are foreigners are all variables that are significant in explaining the SWV of day labourers in Windhoek.

In the first few estimations, income was included as a variable because the literature (Blaauw et al. 2018; Diener \& Oishi 2000; Diener et al. 1993) states that income plays a big part in explaining the SWB of day labourers around the world. In this study, it was not the case. Income was then discarded as a variable after a few estimations, as the variable was not significant in explaining the SWB of day labourers in Pretoria and Windhoek. The reason for this could be that the labourers earn so little that a small increase in their wages would not make a big difference in their SWB. The results of the study vindicate the importance of whole life satisfaction (WLS) as a criterion for people's quality of life (Feldman 2008).

\section{Policy recommendations}

In South Africa, municipalities are required to develop, implement and manage strategies for local economic development through the development of integrated development plans (IDPs). The danger is that an IDP can merely be a document on a shelf, instead of giving practical meaning to the aspirations of the people living in the municipality. The informally employed often work and live in a regulatory vacuum, vulnerable to exploitation and other adverse labour market effects. However, they remain a permanent feature of the local economic landscape within the boundaries of the local authority.

In practical terms, the managerial implications of this study are the need to engage with all levels of the labour market in the formulation of municipalities' IDPs and accompanying strategies regarding living conditions, food security and the socio-economic integration of migrant day labourers (issues identified in this study). As a second step, coordination between the municipalities and the important role of NGOs can be improved to the benefit of all.

In Namibia, for example, the non-governmental organisation (NGO) Men on the Side of the Road (MSR) works closely with day labourers.

This organisation supports them by helping them to gain the necessary skillsets to start their path to self-sustainability and self-employment. They collaborate with the local and national governments, businesses and also individuals who are interested in helping to reduce unemployment and poverty in the country.

Men on the Side of the Road originated in Cape Town, South Africa, in 1999 (founded by Charles Maisel) with the vision to empower the unemployed men and women who gather at job sites to compete in the job market (Ashoka 2000).

It is recommended that similar initiatives in South Africa can benefit from improved coordination with local authorities to provide practical assistance to informal workers to help them to find better and more permanent forms of employment. It can also offer help with labour law violations, such as withholding of payment after work was completed. Several examples of success in this regard are found in the USA.

In the USA, many of these day labour centres occurred primarily as a result of the National Day Laborer Organising Network (NDLON), an alliance of independent worker centres that establish and monitor rules in day-labour markets. These worker centres function as hiring halls from 
which day-labour markets can be more effectively regulated (Theodore, Valenzuela \& Meléndez 2009). This is a direct policy intervention that sets wage rates, develop joballocation systems and assist day labourers in redressing wage theft (Theodore et al. 2009). Research suggests that these interventions are effective in raising wages, improving health and safety on the job and providing a needed regulatory intervention in casualised labour markets (Theodore 2016; Visser 2017).

We argue that, in South Africa, through collaborating with local government, similar centres in South Africa and Namibia can also provide some of these benefits. Furthermore, it can play an important role in providing access to legal remedy as well as other social services. We do not suggest that a policy of worker centres on its own can provide a longterm solution for the multiple regulatory challenges that the informally employed face every day. That being said, worker centres can be a promising vehicle for short-term assistance to counteract some of the perverse realities in informal labour markets, such as wage theft, undue exposure to health and safety hazards and other forms of exploitation of casualised labour. This, in itself, can play an important positive role in improving the levels of SWB of this often marginalised section of our urban communities.

\section{Areas for further studies}

In view of the work of Rojas (2013), more qualitative research needs to be conducted on the education of the day labourers and why certain levels of education seem to increase the SWB of the day labourers. Empirical evidence gained in this way can inform researchers and policy makers whether informal employment in South Africa and Namibia is per definition associated with a worse quality of life or whether other endogenous factors are also at play.

The results seem to show that family life plays a more prominent role in the SWB of day labourers in Windhoek (mainly Namibian nationals) than the day labourers in Pretoria (mainly foreign migrants). This is contrary to other literature that states that migrants are acutely aware of their responsibilities towards families in their sending countries, but given the depressed wage levels in the day labour market, both foreign and local day labourers find it difficult to support their families (Theodore et al. 2017). This implies that more research is needed to focus on these perceived differences.

Lastly, further studies need to focus on building an SWB index for day labourers overall.

Specific questionnaires developed for this purpose should include objective and subjective as well as economic and non-economic indicators. The work of Greyling and Tregenna (2017), in constructing the first such composite index of quality of life in South Africa, can serve as a benchmark and point of departure in this regard.
The aforementioned areas of further research may provide policymakers with additional information on issues of quality of life, enabling them to provide practical assistance for the informally employed as part of their broader local economic development strategy and management.

\section{Acknowledgements}

The article is based on the thesis by Anthonie M. (Anton) van Wyk for the degree of Master of Commerce in Economics at the North-West University in 2019, titled 'Investigating the subjective well-being of the informally employed: A case study of day labourers in Windhoek and Pretoria', which is available here: https:/ / repository.nwu.ac.za/handle/10394/33144.

\section{Competing interests}

The authors declare that they have no financial or personal relationships that may have inappropriately influenced them in writing this article.

\section{Authors' contributions}

A.M.V.W. analysed the data provisionally and was responsible for the first draft of the manuscript. P.F.B. assisted with the development of the survey instrument, fieldwork and writing of the subsequent drafts of the manuscript. A.P. assisted with the analysis of the data and writing of the subsequent drafts of the manuscript. R.S. assisted with the development of the survey instrument and fieldwork and commented on the various drafts of the manuscript. R.F. assisted with the fieldwork and identification of the hiring sites in Windhoek and provided local context for the manuscript.

\section{Funding information}

The authors acknowledge funding from the National research Foundatuion as well as the North-West University (NWU) in the form of a CDG grant.

\section{Data availability statement}

The data are owned by the NWU.

\section{Disclaimer}

The views and opinions expressed in this article are those of the authors and not an official position of the institutions or funders.

\section{References}

Andrews, F.M. \& Whitey, S.B., 1976, Social indicators of well-being, Plenum, New York, NY.

Ashoka, 2000, Charles Maisel, men on the side of the road, viewed 28 February 2020, from https://www.ashoka.org/en/story/charles-maisel-men-side-road.

Blaauw, P.F., 2010, 'The socio-economic aspects of day labouring in South Africa', DCom thesis, Department of Economics \& Econometrics, University of Johannesburg, South Africa.

Blaauw, P.F., Botha, I. \& Schenck, C.J., 2018, 'The subjective well-being of day labourers in South Africa: The role of income and geographical location', South African Journal of Economic and Management Sciences 21(1), a2087. https://doi. org/10.4102/sajems.v21i1.2087 
Blaauw, P.F., Louw, H. \& Schenck, C.J., 2006, 'The employment history of day labourers in South Africa and the income they earn - A case study of day labourers in Pretoria', South African Journal of Economics and Management Sciences 9(4) 1-14. https://doi.org/10.4102/sajems.v9i4.1034

Blaauw, P.F. \& Pretorius, A.M., 2012, 'The determinants of subjective well-being in South Africa - An exploratory enquiry', Journal of Economic and Financial Sciences 6(1), 179-194. https://doi.org/10.4102/jef.v6i1.283

Blanchflower, D.G. \& Oswald, A.J., 2004, 'Well-being over time in Britain and the USA', Journal of Public Economics 88, 1359-1386. https://doi.org/10.1016/S0047 2727(02)00168-8

Botha, F. \& Booysen, F., 2011, 'The gold of one's ring is not far more precious than the gold of one's heart: Reported happiness among married and cohabitating South African adults', Paper presented at the bi-annual conference of the Economic Society of South Africa, 04-07 September 2011, University of Stellenbosch, South Africa.

Daykin, A.R. \& Mofatt, P.G., 2002, 'Analysing ordered responses: A review of the ordered-probit model', Understanding Statistics 1(3), 157-166. https://doi. org/10.1207/S15328031US0103_02

Diener, E., 1984, 'Subjective well-being', Psychological Bulletin 95(3), 542-575. https://doi.org/10.1037/0033-2909.95.3.542

Diener, E., 2009, 'Subjective well-being', in E. Diener (ed.), The science of well-being pp. 11-58, Springer, Dordrecht.

Diener, E. \& Chan, M.Y., 2011, 'Happy people live longer: Subjective well-being contributes to health and longevity', Applied Psychology: Health and Wellbeing 3(1), 1-43. https://doi.org/10.1111/j.1758-0854.2010.01045.x

Diener, E. \& Oishi, S., 2000, 'Money and happiness: Income and subjective well-being across nations', in E. Diener \& E.M. Suh (eds.), Culture and subjective well-being, pp. 185-218, The MIT Press, Cambridge, MA.

Diener, E., Oishi, S. \& Lucas, R.E., 2003, 'Personality, culture, and subjective wellbeing: Emotional and cognitive evaluations of life', Annual Reviews 54(1), 403-425. https://doi.org/10.1146/annurev.psych.54.101601.145056

Diener, E., Sandvik, E., Seidlitz, L. \& Diener, M., 1993, 'The relationship between income and subjective well-being: Relative or absolute?', Social Indicators Research 28(3), 195-223. https://doi.org/10.1007/BF01079018

Easterlin, R.A., 2001, 'Editorial: Subjective well-being and economic analysis: A brief introduction', Journal of Economic Behavior \& Organization 45, 225-226. https:// doi.org/10.1016/S0167-2681(01)00143-3

Easterlin, R.A., McVey, L.A., Switek, M., Sawangfa, O. \& Zweig, J.S., 2010, 'The happiness-income paradox revisited', PNAS 107(52), 22463-22468. https://doi org/10.1073/pnas.1015962107.

Feldman, F., 2008, 'Whole life satisfaction concepts of happiness', THEORIA 74(3) 219-238. https://doi.org/10.1111/j.1755-2567.2008.00019.x

Ferrer-i-Carbonell, A. \& Frijters, P., 2004, 'How important is methodology for the estimates of the determinants of happiness?', Economic Journal 114(497) 641-659. https://doi.org/10.1111/j.1468-0297.2004.00235.x

Greene, W.H., 1993, Econometric analysis, 2nd edn., Macmillan Publishing Company, New York, NY.

Greyling, T., 2018, 'Internet access and its relationship to subjective well-being in a developing region', South African Journal of Economic and Management Sciences 21(1), a1841. https://doi.org/10.4102/sajems.v21i1.1841.

Greyling, T. \& Tregenna, F., 2017, 'Construction and analysis of a composite quality of life index for a region of South Africa', Social Indicators Research 131(3), 887-930. https://doi.org/10.1007/s11205-016-1294-5
Helliwell, J.F., Huang, H. \& Wang, S. 2019, Changing world happiness (In World Happiness Report 2019), viewed 27 February 2020, from https://s3.amazonaws. com/happiness-report/2019/WHR19.pdf.

Louw, H., 2007, 'Men at the margins: Day labourers at informal hiring sites in Tshwane', $\mathrm{PhD}$ thesis, Department of Social Work, University of South Africa, Pretoria.

Mackerron, G., 2012, 'Happiness economics from 35,000 feet', Journal of Economic Surveys 26(4), 705-735. https://doi.org/10.1111/j.1467-6419.2010.00672.x

Mahadea, D. \& Ramroop, S., 2015,'Influences on happiness and subjective well-being of entrepreneurs and labour: Kwazulu-Natal case study', South African Journal of Economic and Management Sciences 18(2), 245-259.

Møller, V., 2007, 'Quality of life in South Africa: The first ten years of democracy', Socia Indicators Research 81(2),181-201. https://doi.org/10.1007/s11205-006-9003-4

Møller, V. \& Devey, R., 2003,'Trends in living conditions and satisfaction among poorer older South Africans: Objective and subjective indicators of quality of life in the October Household Survey', Development Southern Africa 20(4), 1-21. https:// doi.org/10.1080/0376835032000124475

Møller, V. \& Schlemmer, L., 1989, 'South African quality of life: A research note', Social Indicators Research 21(3), 279-291. https://doi.org/10.1007/BF00303787

Namibia Statistics Agency, 2016, The Namibia Labour Force Survey, 50-51, 2016, Government Printers, Windhoek.

Posel, D.R. \& Casale, D.M., 2011, 'Relative standing and subjective well-being in South Africa: The role of perceptions, expectations and income mobility', Social Indicator Research 104(2), 195-223. https://doi.org/10.1007/s11205-010-9740-2

Proctor, C.L., 2014, 'Subjective well-being', in A.C. Michalos (ed.), Encyclopedia of quality of life and well-being research, pp. 6437-6441, Springer, Amsterdam.

Rojas, M., 2013, 'The subjective well-being of people in informal employment: Empirical evidence from Mexico', HRM: A Global Forum for Empirical Scholarship 1(2), 169-186. https://doi.org/10.1108/EBHRM-04-2013-0006

Rubin, A. \& Babbie, E., 1997, Research methods for social work, 3rd edn., Brooks Cole, Pacific Grove, CA.

Statistics South Africa, 2020, Quarterly Labour Force Survey, Quarter 4, 2019 , Government Printers, Pretoria.

Theodore, N., 2016, Day labor in Seattle: Casa Latina's impact on wages and earnings, National Day Laborer Employment Network, Los Angeles, CA.

Theodore, N., Blaauw, D., Pretorius, A. \& Schenck, C., 2017, 'The socioeconomic incorporation of immigrant and native-born day labourers in Tshwane, South Africa', International Migration 55(1), 142-156. https://doi.org/10.1111/imig.12311

Theodore, N., Valenzuela, Jr., A. \& Meléndez, E., 2009, 'Worker centers: Defending labor standards for migrant workers in the informal economy', International JournalofManpower30(5),422-436. https://doi.org/10.1108/01437720910977634

Tradingeconomics, 2019, Namibia unemployment rate, viewed 10 August 2019, from https://tradingeconomics.com/namibia/unemployment-rate.

Valenzuela, Jr., A., Theodore, N., Meléndez, E. \& Gonzalez, A.L., 2006, On the corner: Day labor in the United States, UCLA, Los Angeles, CA.

Van Aardt, C.J., De Clercq, B. \& Meiring, J., 2019, 'The stochastic determinants of happiness in South Africa: A micro-economic modelling approach', Journal of Economic and Financial Sciences 12(1), a228. https://doi.org/10.4102/jef.v12i1.228

Viljoen, K., Schenck, C.J. \& Blaauw, P.F., 2012, 'The role and linkages of buy-back centres in the recycling industry: Pretoria and Bloemfontein', Acta Commerci centres in the recycling industry: Pretoria and B
$12(1), 1-12$. https://doi.org/10.4102/ac.v12i1.125

Visser, M.A., 2017, 'A floor to exploitation? Social economy organizations at the edge of a restructuring economy', Work, Employment, and Society 31(5), 782-799. https://doi.org/10.1177/0950017016638020 